\title{
Continuation of fishing subsistence in the Ukrainian Neolithic: diet isotope studies at Yasinovatka, Dnieper Rapids
}

\author{
Chelsea Budd $^{1} \cdot$ Inna Potekhina ${ }^{2} \cdot$ Malcolm Lillie $^{1}$ \\ Received: 1 November 2019 / Accepted: 14 January 2020 / Published online: 3 February 2020 \\ (C) The Author(s) 2020
}

\begin{abstract}
Yasinovatka is one of around 30 prehistoric cemetery sites of fisher-hunter-foragers located along the Dnieper River in southern Ukraine. Dating to $c$. 5540-4930 cal BC, the skeletal remains at Yasinovatka suggest that around sixty-eight individuals were interred at the cemetery, during three broad phases of interment: A-type burials (c. 5540-4930 cal BC), Б1 pit burials (c. 5550$4750 \mathrm{cal} \mathrm{BC}$ ), and 52 pit burials (c. 4980-4460 cal BC). The burials are characterized, in part, by the inclusion of a number of Mariupol-type plates of boar tusk, in addition to deer tooth pendants, Unio shells, knife-like flint blades, Cyprinidae teeth, sherds of Neolithic pottery, and significant deposits of ochre in the later burial pits. Here we analyse $\delta^{13} \mathrm{C}$ and $\delta^{15} \mathrm{~N}$ values for 50 human bone collagen samples from the site. The majority of the isotope results show a fisher-hunter-forager population reliant predominantly on freshwater aquatic proteins, which is in keeping with previous dietary isotope studies in the area. Two individuals however have $\delta^{15} \mathrm{~N}$ values that are clearly depleted when compared with the main population; these reflect dietary protein intakes based on plant and animal terrestrial resources rather than the predominant focus on aquatic resources. Notably, the $\delta^{13} \mathrm{C}$ values of these anomalous individuals are not enriched compared with the fauna samples analysed from the region; this supports the possibility that they were incomers to the area, potentially from a nearby agrarian population.
\end{abstract}

Keywords Neolithic $\cdot$ Stable carbon and nitrogen isotopes $\cdot$ Palaeodietary reconstruction

\section{Introduction and background}

The precise chronology of the Dnieper Rapids region has received detailed review (Gokhman 1966, Telegin 1968, 1973, Telegin and Potekhina 1987, Telegin et al. 2002, also Biagi et al. 2007), and periodization in Ukraine has been refined with the integration of recent AMS radiocarbon dates (Lillie et al. 2009, 2017; Nikitin et al. 2010, 2017). Currently, phases of burial activity are represented for the Epipalaeolithic $(c$. 10,200-8000 cal BC), Mesolithic (c. 7300 cal BC), Neolithic (c. 5500-5000 cal BC), and Eneolithic periods (c. 4400 cal BC) (Lillie et al. 2009; Telegin et al. 2002), but, given the heterogeneity in terms of prehistoric activity in Ukraine,

Malcolm Lillie

malcolm.lillie@umu.se

1 Department of Historical, Philosophical and Religious Studies, Umeå University, S-90187 Umeå, Sweden

2 Department of Bioarchaeology, Institute of Archaeology, National Academy of Sciences of Ukraine, Kiev 04210, Ukraine refining the exact boundaries of the periods remains a complex issue.

One of the key factors when studying social developments across the Late-Glacial into the middle part of the current Interglacial period, i.e. the Epipalaeolithic through to the Eneolithic periods in Ukraine, is how the Neolithic period is defined; and indeed this is the case in other areas of Eastern Europe. In the 'Western' school of thought, the debate surrounding the characterization of the Neolithic period is on-going (Pluciennik 1998, Zvelebil 1998, Thomas 2002, Anthony 2007, Fernández-Domínguez and Reynolds 2017); but the term is often associated with the beginnings of food production as opposed to food extraction (Price 2000; Anthony 2007) (amongst other variables such as pottery, sedentism, demographic shifts, evidence for increasing social complexity etc. (Barker 2009, Sherratt 2016)).

In Ukraine, the onset of the Neolithic period has often been defined by the introduction of pottery (although this occurs in purely Mesolithic contexts, with the Bug-Dniester culture of southwestern Ukraine having ceramics at c. 6200calBC (Anthony 2007:149), and it has its origins to the northeast in 
the Middle Volga River Valley where the Elshanka culture of the Samara region produced ceramics using the coiling method (ibid. 2007)), alongside diversification in lithic technologies, and a shift in observed burial rites (cf. Gronenborn 2003; Jacobs 1993; Lillie 1998; Telegin et al. 2003; Telegin and Titova 1993). The underlying assumption driving this characterization is that a change in technical culture reflects a change in social practices (cf. Motuzaite Matuzeviciute 2014:137). Recent research has shown that these changes are heterogeneous across Ukraine, and that the rate at which changes occur can be protracted (e.g. Anthony 2007). Notably though, irrespective of the socio-technical aspects, the characterization of Neolithic sites in Ukraine generally lacks the major socioeconomic transformations of a food economy that transitions from the extraction of resources to the production of resources; a quantifier that plays a distinct role in the identification of Neolithic sites in North-western Europe.

In Ukraine, one of the dominant factors characterizing the research framework to date is the ubiquitous evidence for a continued reliance on aquatic proteins well into the Neolithic period. Whilst domesticates are integrated into Bug-Dniester subsistence strategies from the end of the VIIth millennium BC in southwestern Ukraine, the earliest reliable isotopic evidence for a reliance on terrestrial domesticates further east, in the Dnieper region, only occurs at the onset of the Eneolithic period, with the Trypillia farming culture, and in the Dnieper River region at the site of Molyukhov Bugor at c. 4000 calBC (Lillie et al. 2011).

This pattern of continued dependence on aquatic proteins into the Neolithic period is rarely observed in NW Europe, if observed at all (e.g. debate in Richards et al. 2003, Milner et al. 2004 and references therein), but, by contrast, it is seen elsewhere in Eastern Europe, and in the Baltic region there is clear evidence for continuity across the Mesolithic-Neolithic transition (e.g. Eriksson 2006; Eriksson et al. 2003). Elsewhere in the Eurasian steppe zone (in northeastern Kazakhstan) Svyatko et al. (2015) have documented the fact that a continued reliance on freshwater resources occurs into the Eneolithic and Bronze Age periods. One potential factor that might explain this subsistence choice in Ukraine is the possibility of a Black Sea deluge event at c. 7300-7200 BP (Ryan et al. 2003; Yanchilina et al. 2017); indeed the potential effects of this flood event on prehistoric populations is examined in other archaeological research (Turney and Brown 2007; Bikoulis 2015). (It should be noted that the occurrence of a catastrophic Black Sea flooding event remains widely debated in the academic literature (see Yanchilina et al. 2017, Goldberg et al. 2016). However, if a flooding event did occur, it is possible that land that hitherto would have provided a fertile environment for agrarian or pastoral practices was no longer viable (as the result of inundation and/or salinification processes, Yanchilina et al. 2017), thereby potentially creating increased competition for established aquatic resources.
Given that existing dietary studies show a continuation of the consumption of aquatic proteins, the core aims of this project are to characterize the nature of diet at Yasinovatka, and also to test whether there are any isotopic differences in human diet between the two (probable) cultural groups (the Surskaja A-type burials and the Dnieper Donets Mariupol-type; E-pit burials). Lillie (1998) has previously noted that the concentration of cemeteries in and around the Dnieper Rapids, at a point where a stable and predictable resource, such as migratory and other fish are easily harvested, may well reflect the establishment of ancestral rights of access to this food source.

\section{Yasinovatka: Boar tusk plates, deer tooth pendants, and ochre burials}

Yasinovatka is situated on the high left bank of the river Dnieper (Fig. 1). The stage Б cemetery area is a subrectangular pit, which was highlighted during excavation by red staining associated with the ochre applied to Neolithic burials in the region (Fig. 2). The cemetery contained 68 individuals; 51 adults (36 males and 15 females), four adolescents and nine children (Telegin and Potekhina 1987). In general, individuals were interred in the extended supine position, however some variation occurs. A number of skeletons were severely contracted, which is indicative of swaddling/ wrapping of the body prior to burial (Telegin and Potekhina 1987). Amongst the burial inventory from Yasinovatka are a number of Mariupol-type plates of boar tusk, deer tooth pendants, Unio shells, knife-like flint blades, Cyprinidae teeth, sherds of Neolithic pottery, and a poorly preserved bone awl. It is of some note that no pottery was found associated with the stratigraphically earlier A-type grave pits (Fig. 3).

The cemetery at Yasinovatka has three phases of interment; A-type, E1, and 52 (Telegin and Potekhina 1987). The earliest phase of interment is attributed to the latest stage of the Neolithic Surskaja cultural group (c. 5100-5000 cal BC) (Kotova 2010), as the A-type phase is characterized by individual and paired oval burials pits, the presence of deer tooth pendants and fish teeth (Telegin and Potekhina 1987). Burials from the 5 -pit (Б1 and Б2) are attributed to the Dnieper Donets (Mariupol-type cemeteries) cultural group (c.70004000 cal BC) (Telegin et al. 2002); as the E-pit is characterized by collective burial (Fig. 3), the presence of pottery sherds and fragmented vessels, and the use of red ochre.

A notable burial at the site is individual number 45, an 18 25 year old male who was buried with 11 plates made from boar tusk enamel (Fig. 4). Telegin and Potekhina (1987:57) note that the position of the boar tusk plates in the grave suggests they were sewn onto the sleeves of a garment, with the enamel on the outside.

The artefactual and funerary differences observed between the stage A burials and the stage 5 burials (see 
Fig. 1 The Dnieper Rapids region, showing locations of cemeteries studied by Lillie (1998). 1-Dereivka I and II, 2-

Vasilyevka V, III and II, 3-

Nikolskoye, 4-Yasinovatka. $\Delta$-Mesolithic, $\Delta$-Neolithic

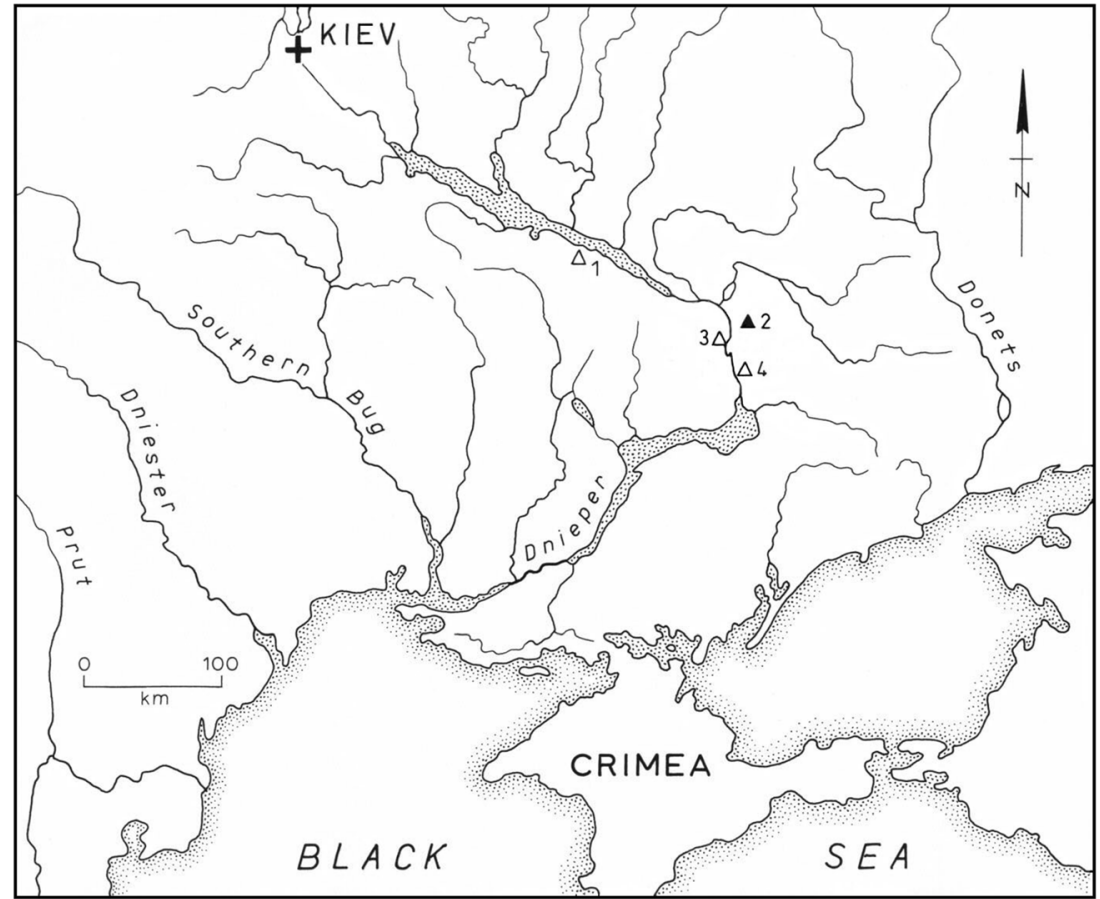

Figs. 2 and 3; Table 1) indicate that there is a shift away from the earlier (essentially Mesolithic) fisher-hunterforager mode of interment in individual or paired grave pits, towards a more communal mode of interment, which is perhaps aimed at reinforcing the group identity. Interestingly, this mode of interment is often associated
Fig. 2 Yasinovatka Cemetery Grave pit Б (1 and 2) (after Telegin and Potekhina 1987)

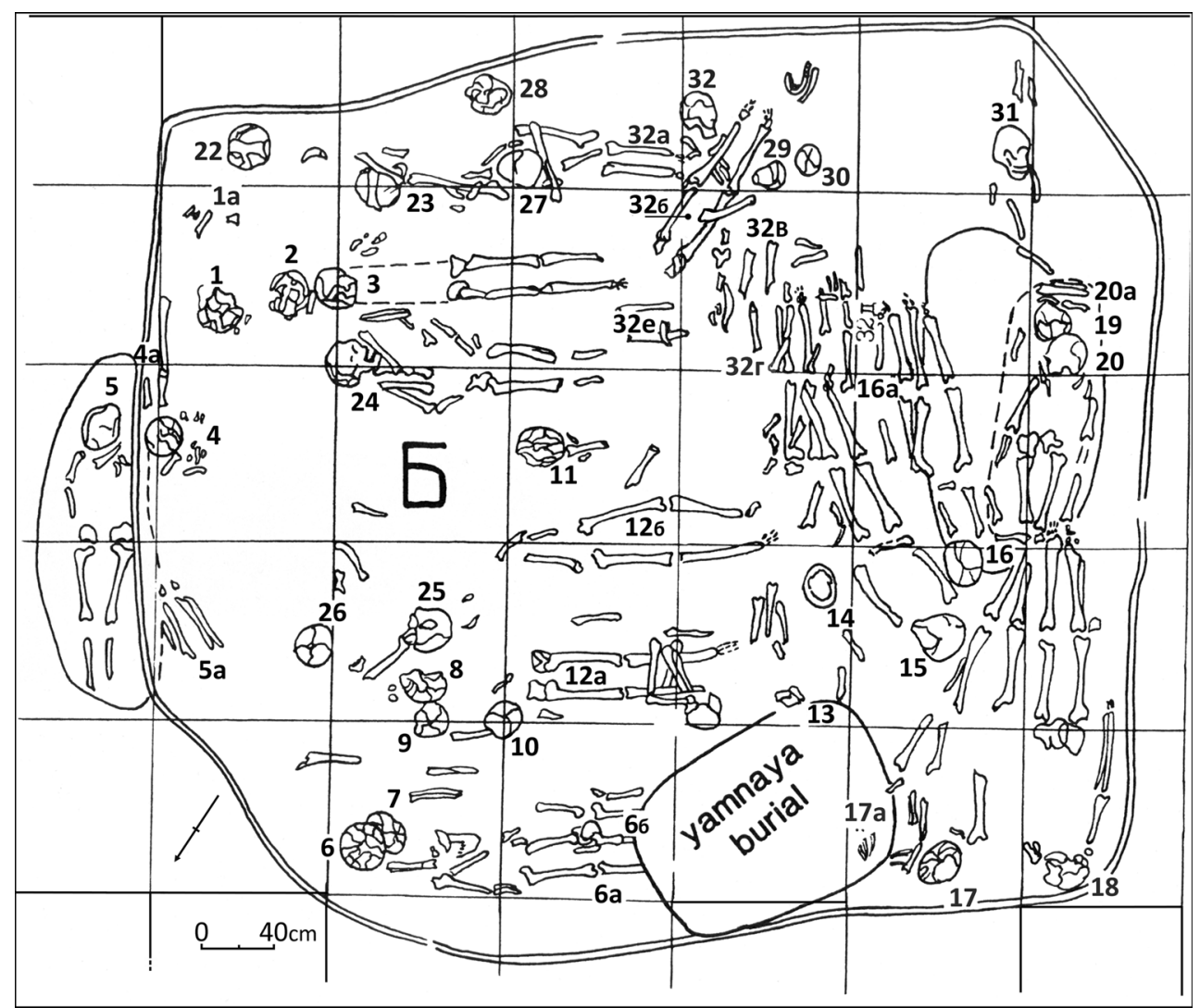


Fig. 3 Yasinovatka Cemetery plan (a) and profile (b). Legend: I-Stones; II \& III-Outlines of Grave Pits; IV—Black Soil; VSubsoil; VI-Pit Fill; VII-Loess (after Telegin and Potekhina 1987)
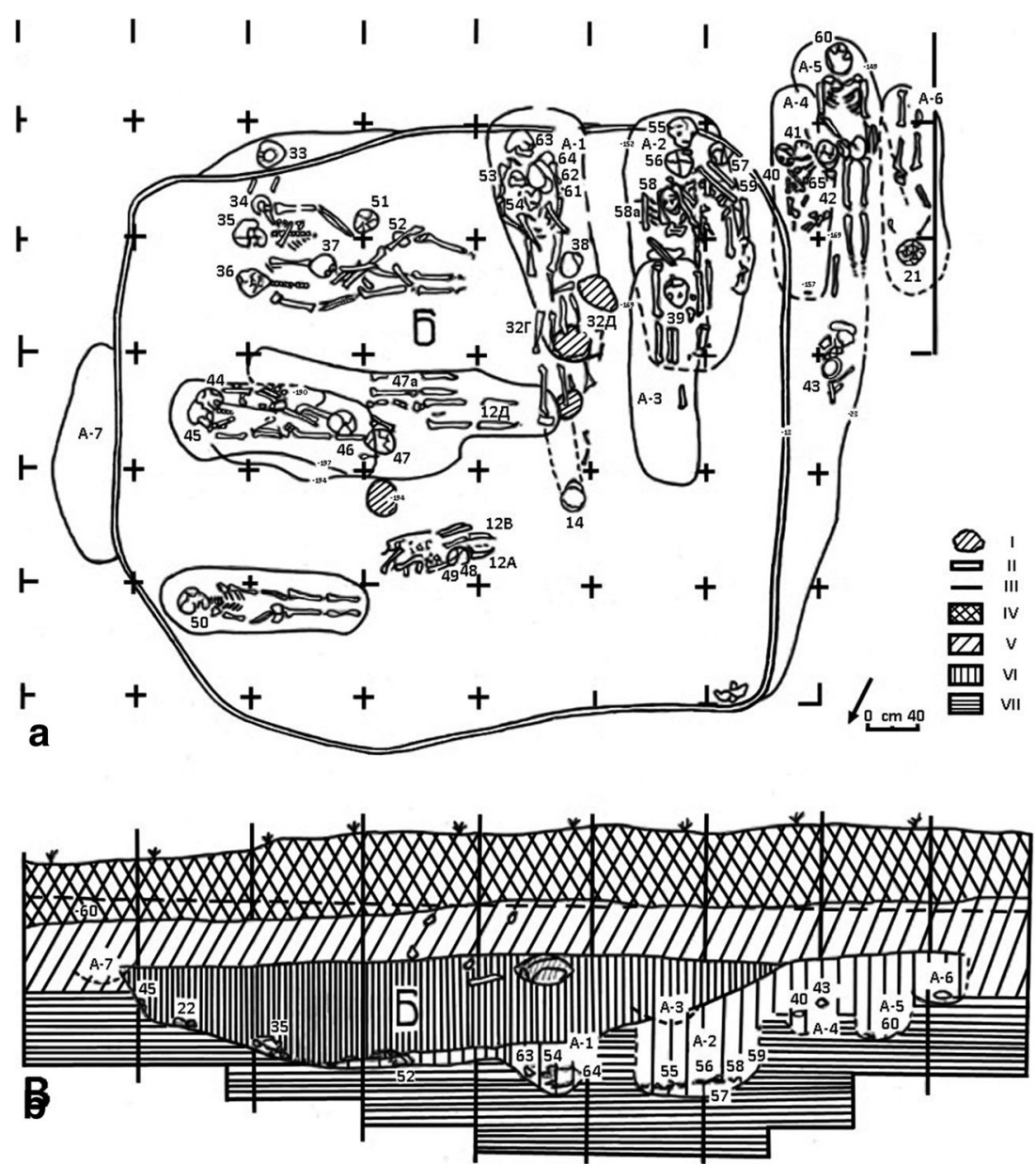

more with farming societies, wherein it is interpreted as representing an attempt to reinforce social ties to the collective (Meyer et al. 2012, Pearson 1999).

As this shift is occurring at a time when increasing contacts with incoming agro-pastoralists is in evidence, we are potentially seeing a societal reaction against the new contacts and/or trade with neighbouring groups, or against the integration of immigrants from these new groups into the established fisherhunter-forager communities in and around the Dnieper region (or a combination of these factors).

Interestingly, the stratigraphic evidence (Fig. 3) supports the probability that the 5-pit cut through and disturbed the existing A-type burials, and during the excavations, the $\bar{B}$ burials were found to be in a greater state of disarticulation, perhaps suggesting a similar situation to that in evidence further afield in the chambered tombs of north-western Europe, where the dead are regularly repositioned within the tomb as new interments are made (Telegin and Potekhina 1987; Whittle et al. 2011; Salanova et al. 2018; Chambon et al. 2017). These observations suggest that between stages A to 51 there is some degree of socio-political shift/re-orientation in the ritual articulation of the group. The reasons and meaning behind this is difficult to disentangle given the general continuities in material culture, although the appearance of ceramics, changes in lithic inventories and the use of ochre in association with the $\bar{E}$ group may be the key indicators of the vectors for change, in that it is the heightened contacts with incoming agro-pastoralists that stimulates a reaction in these groups.

However, in addition to this, it is entirely possible that whilst the different culture group nomenclature is a modern construct, these could actually be highlighting an even more substantial situation wherein the Surskaya group is actually replaced by the Dnieper-Donets culture group at the population level, and whilst the cemetery continues in use, the population that inters its dead in the 5 stages is in fact a completely new fisher-hunter-forager population that has moved into this region and displaced the indigenous/earlier groups. Obviously, at this stage of the analysis the above scenarios are somewhat hypothetical, but the application of DNA analyses to the cemeteries in this region could provide fundamental insights into population dynamics and shifts in the origins of the groups that are using these burial grounds. 
Fig. 4 Boar tusk plates that were probably sewn on to the clothing of individual 45 at Yasinovatka (after Telegin and Potekhina 1987:58, Fig. 30)

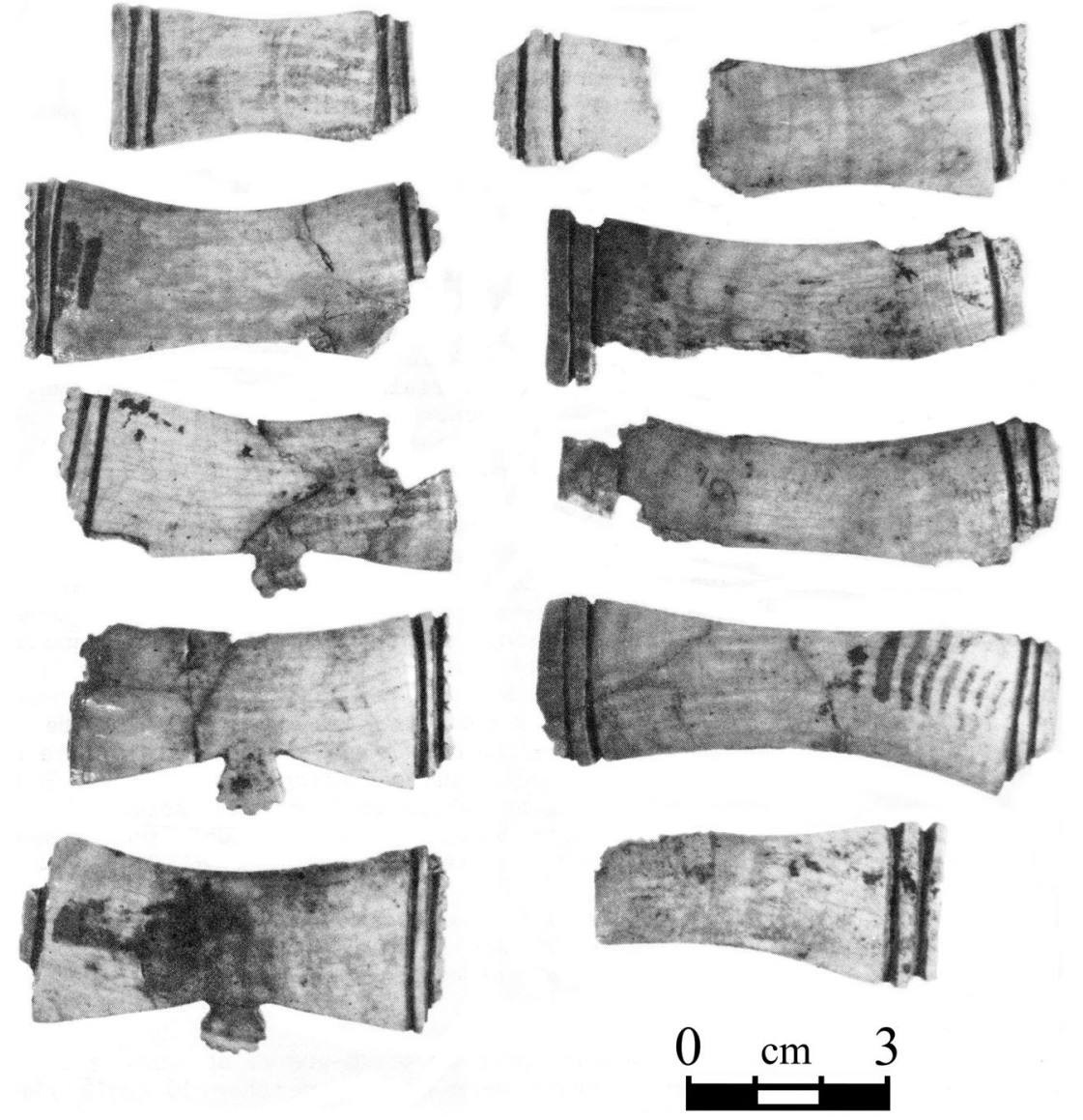

\section{Chronology and diet in the Dnieper Rapids region: radiocarbon dating and stable isotope studies}

The precise nature of chronological developments in the region is complex, and a number of robust reviews are present in the literature (Telegin et al. 2002; Lillie et al. 2009). At Yasinovatka, the absolute chronology is based on 10 radiocarbon ages of skeletal collagen. The radiocarbon dates from the site initially place the earliest evidence for occupation at c. $6465 \pm 60$ BP (OxA-6163) (5476$5271 \mathrm{cal} \mathrm{BC}$ at 95\%, using OxCal 4.2.2 and IntCal13), with subsequent layers dated to $6121 \pm 34 \mathrm{BP}$ (OxA-
17,500) (5209-4959 cal BC at 95\%, using OxCal 4.2.2 and IntCal13) (Fig. 5, modelled dates).

Existing radiocarbon dating at the site of Yasinovatka (and at proximal sites in the region), has produced evidence to support the presence of a radiocarbon freshwater reservoir effect; via the dating of human bone, red deer teeth, and fish teeth (Lillie et al. 2009). In oversimplified terms, a freshwater reservoir effect can cause an anomalous ${ }^{14} \mathrm{C}$ offset in the radiocarbon age of a sample that is either from a freshwater context, or that has consumed freshwater resources; specifically it can produce a ${ }^{14} \mathrm{C}$ age that is artificially 'older' than its true radiocarbon age (Ascough et al. 2005, Philippsen 2013). At Yasinovatka, the radiocarbon ages suggest a potential

Table 1 Burial data for phasing, culture affiliation, absolute dating and associated artefact inventories for Yasinovatka

\begin{tabular}{|c|c|c|c|c|}
\hline Burial pit & Cultural group & Date & Burials & Associated grave goods/finds \\
\hline A-type & Surskaja & $5540-4930 \mathrm{cal} \mathrm{BC}$ & $\begin{array}{l}5,19,20,20 \mathrm{a}, 21,31,32,38,40 \\
54,55,57,59,60,63,39\end{array}$ & $\begin{array}{l}\text { Deer tooth pendants, flint knife-like blade, } \\
\text { Unio shell, cyprinidae teeth }\end{array}$ \\
\hline Б1 & Mariupol & $5550-4750 \mathrm{cal} \mathrm{BC}$ & $\begin{array}{l}1,3,4,6,7,8,9,10,11,24,25,26 \\
27,28,34,35,36,37,45\end{array}$ & $\begin{array}{l}\text { Boar tusk plates, red ochre, pottery sherds, } \\
\text { fragmented vessels }\end{array}$ \\
\hline Б2 & Mariupol & $4980-4460 \mathrm{cal} \mathrm{BC}$ & $15,17,17 \mathrm{a}, 18$ & Red ochre, large flint tools \\
\hline
\end{tabular}

Only individuals who produced isotope results and as such are analysed in this study are listed (after Telegin and Potekhina 1987) 


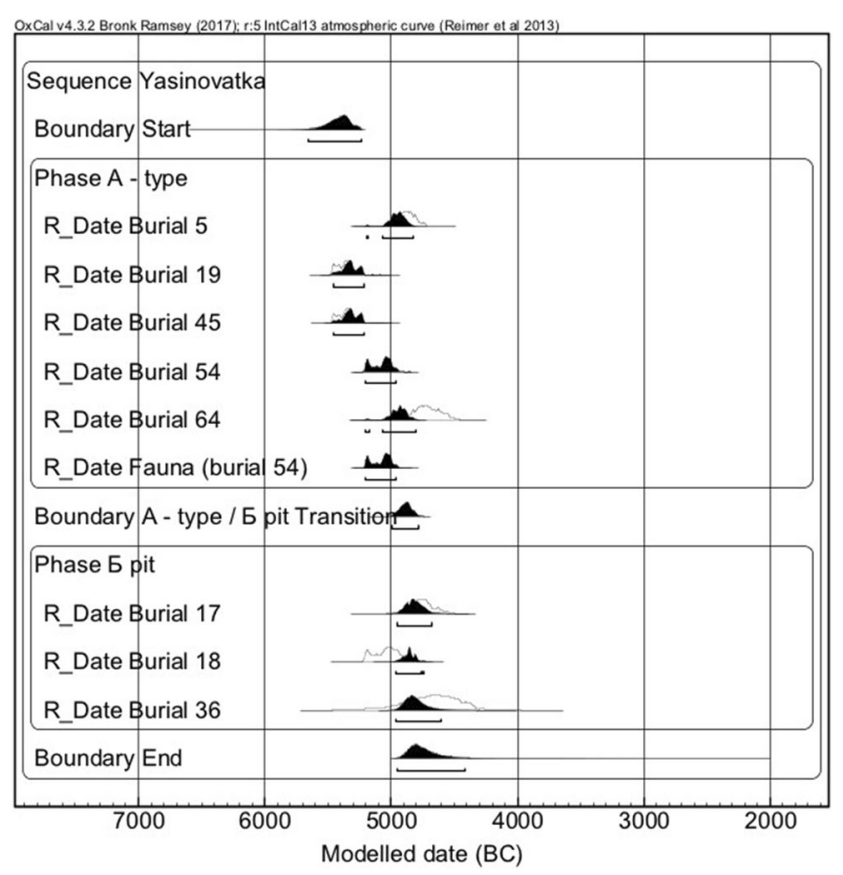

Fig. 5 Modelled radiocarbon ages of human and animal skeletal collagen from Yasinovatka (OxCal v4.3.2 (2017), 95\%, IntCal13 (Reimer et al. 2013)). Source: Lillie 1998, Lillie et al. 2009

reservoir effect of c. 470 years (see Fig. 6), with surrounding Neolithic sites in the Dnieper Rapids region producing radiocarbon offsets of $c$. 100-400 years (Lillie et al. 2009:259-62), but the degree of offset is not systematic as the degree of freshwater resource consumption, as indicated by the $\delta^{15} \mathrm{~N}$ values on these individuals, can indicate an offset closer to the terrestrial baseline where the values are lowered (i.e. values towards $11-12 \%$ o will produce a limited offset in radiocarbon years), whilst elevated values can cause the degree of offset to increase to the 470 years attested by individual 54 at Yasinovatka. Therefore, any human individuals that produce elevated $\delta^{15} \mathrm{~N}$ values should potentially be considered to have the reservoir effect, and any radiocarbon ages on these individuals should be examined carefully.

To date, $c .170$ human, fauna, and fish bone collagen (or dentine) samples have been analysed for diet isotope studies from the Epipalaeolithic to Eneolithic cemeteries in the Dnieper region (Lillie and Richards 2000; Lillie et al. 2003, 2011; Lillie and Jacobs 2006). The prevailing conclusion of these studies demonstrates variability in access to dietary proteins across these periods, with the notable factor that the consumption of aquatic proteins is distinct during every phase in the study period (Lillie 1998; Lillie and Richards 2000; Lillie et al. 2003; Lillie and Jacobs 2006; Lillie and Budd 2011; Lillie et al. 2011). Previous dietary isotope studies into the human populations at Yasinovatka highlighted depleted $\delta^{13} \mathrm{C}$ values $-22.4 \pm 0.3 \%$, and elevated $\delta^{15} \mathrm{~N}$ values $14.2 \pm$ $0.3 \%$, reflecting a diet that incorporates significant quantities of aquatic proteins. The human samples from Yasinovatka have produced the most enriched $\delta^{15} \mathrm{~N}$ values of all sites across the region; being commensurate with Vasilyevka II (Mesolithic), and Nikolskoye (Neolithic).

There are only limited fauna samples from prehistoric sites in the Dnieper Rapids region, which limits the material available for isotope analysis (Lillie et al. 2011). Fewer than twenty wild or domesticated fauna samples have been isotopically analysed from the sites in the study region; and of these samples, only four originate from the sites clustered around Yasinovatka (red deer and Bovidae sp.). At $-19.5 \pm 0.6 \%$ o the $\delta^{13} \mathrm{C}$ values suggest a terrestrial $\mathrm{C}_{3}$ plant signal of $c$. $20.5 \pm 1 \%$ o, and the $\delta^{15} \mathrm{~N}$ values at $6.9 \pm 0.8 \%$ o (Lillie et al. 2011), indicating a terrestrial plant signal of anything from $c$. $1-4 \%$, assuming a trophic enrichment of 5-6\%o (Hedges and Reynard 2007; O'Connell et al. 2012; Fernandes et al. 2014). Whilst this dataset is admittedly limited, if humans at Yasinovatka or proximal sites were consuming a combination of terrestrial plants and fauna we would anticipate $\delta^{13} \mathrm{C}$ values of c. $-19 \pm 0.5 \%$, and $\delta^{15} \mathrm{~N}$ values of c. $10 \pm 1.5 \%$.
Fig. 6 Calibrated radiocarbon ages, showing a reservoir effect for burial 54 at Yasinovatka (OxCal v4.3.2 (2017), 95\%, IntCal13 (Reimer et al. 2013)). Source: Lillie et al. (2009:261)

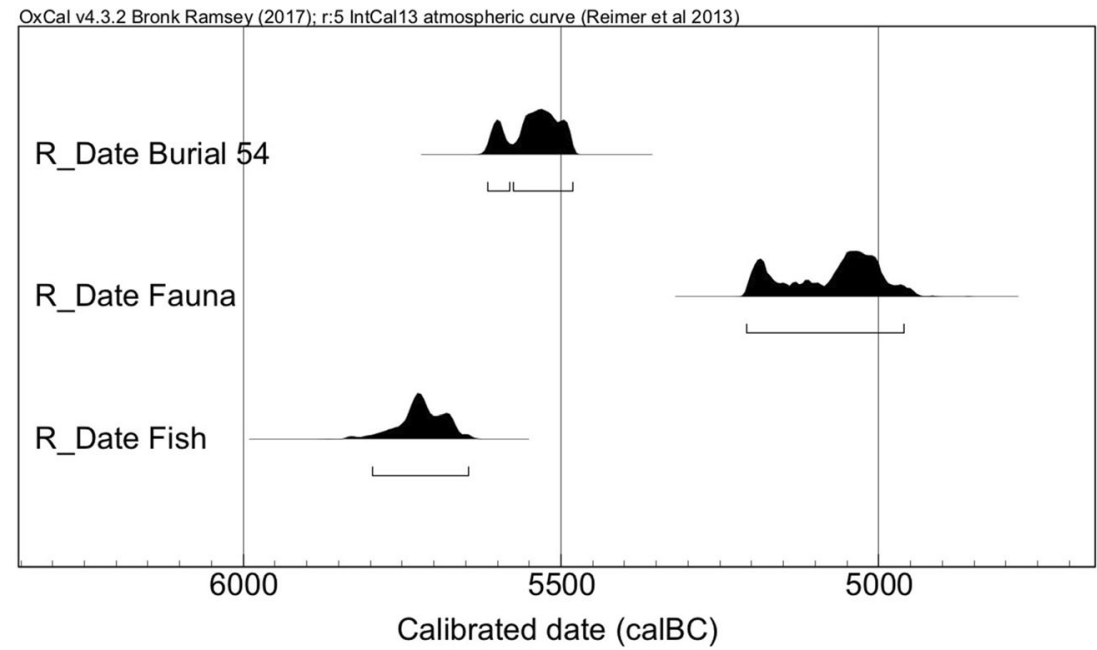




\section{Methods: stable isotope analysis $\left(\delta^{13} \mathrm{C}\right.$ and $\delta^{15} \mathrm{~N}$ )}

Dietary stable isotope analysis is a method now routinely applied in archaeological studies to provide direct evidence for human and animal diets. Many robust reviews and critiques of the methodology exist in the literature (e.g. Hedges and Reynard 2007; Makarewicz and Sealy 2015; Styring et al. 2015), and therefore extensive details of the principles of the method and its application are not repeated here. Briefly, the analysis of carbon and nitrogen ratios from bone collagen allows for a direct assessment of prehistoric dietary pathways, particularly in the last c. 10 years of the individual's life (Schwarcz and Schoeninger 1991). Stable carbon isotope ratios $\left(\delta^{13} \mathrm{C}\right)$ measured from bone collagen can allow us to distinguish between dietary protein from marine, terrestrial and, under some circumstances, freshwater resources (Schwarcz and Schoeninger 1991; Cerling et al. 1997; Richards 2002). In addition, $\delta^{13} \mathrm{C}$ values are influenced by the composition of the local vegetation.

Nitrogen stable isotope ratios $\left(\delta^{15} \mathrm{~N}\right)$ are used to establish the trophic level of an organism in the food web, with $\delta^{15} \mathrm{~N}$ enrichment of c. 3-6\%o (e.g. $\Delta^{15} \mathrm{~N}_{\text {diet-body }}$ ) observed as one progresses up the food chain (Schoeninger and DeNiro 1984; Minagawa and Wada 1984; Hedges and Reynard 2007). The isotope measurements of human and animal bone collagen are biased towards the protein component of ingested foods, which can be used to infer potential sources of dietary carbon, alongside providing information regarding ecological niches, vegetation patterning ( $\mathrm{C}_{3}$ vs. $\mathrm{C}_{4}$ species present) and habitat (Schoeninger and DeNiro 1984; Lee-Thorp and Van der Merwe 1987).

In this study, due to the location of the cemetery and existing dietary isotope studies of sites in the region (Lillie and Richards 2000; Lillie et al. 2011) we anticipate the inclusion of freshwater aquatic protein in the diets of the humans studied. The investigation of aquatic proteins in human diet is often more complex than those related to terrestrial resources, and carbon and nitrogen isotope values from bone collagen with an aquatic signal vary considerably between sites (Katzenberg and Weber 1999; Lillie et al. 2011; Svyatko et al. 2016; Robson et al. 2016; Drucker et al. 2018). In simple terms, bone collagen values from freshwater aquatic species often exhibit $\delta^{13} \mathrm{C}$ ratios that are more depleted than terrestrial animal bone collagen. Robson et al. (2016) analysed bone collagen of freshwater and brackish species (pike, perch, and zander), which produced $\delta^{13} \mathrm{C}$ of 24.2 to $-19.3 \%$, and $\delta^{15} \mathrm{~N}$ values of 5 to $10 \%$. Nitrogen isotope values from freshwater species tend to be more elevated than their terrestrial counterparts (freshwater fish collagen at the Iron Gates produces $\delta^{15} \mathrm{~N}$ values of $10 \pm 1 \%$ (Bonsall et al. 2004)), due to the longer length of the freshwater foodweb. However, some aquatic species, particularly cyprinids, produce noticeably lower bone collagen $\delta^{15} \mathrm{~N}$ values, c. $6 \pm 1 \%$ o (Naito et al. 2013; Schmölcke et al. 2015).

\section{Materials}

Fifty human bone collagen samples were analysed at the Light Stable Isotope Laboratory at Oxford University. Bone collagen was extracted using a modified version of the Longin (1971) method, using acid and $\mathrm{H}_{2} \mathrm{O}$ (MilliQ) washes, freezedrying and isotope measurement on an Elemental Analyser linked to a continuous flow Sercon dual inlet mass spectrometer. Known-value standards are included in order to calibrate (and drift correct) the readings taken from the unknown (bone) samples. Isotopic ratios are calculated with reference to inhouse standards, which for this project included alanine (information regarding other in-house standards, such IAEA standards, were not provided by the laboratory). $\delta^{13} \mathrm{C}$ measurements are reported on the VPDB scale and $\delta^{15} \mathrm{~N}$ is reported with reference to AIR.

Quality control parameters are used in stable isotope analysis to ensure the accuracy of the data produced. These include a collagen yield of $1 \%$ at $5 \mathrm{mg}$ or above, and a $\mathrm{C}: \mathrm{N}$ ratio of between 2.9 and 3.6 (DeNiro and Epstein 1978; DeNiro 1985; Brock et al. 2010). The $\% \mathrm{C}$ and $\% \mathrm{~N}$ of the collagen samples is also calculated as this provides a reliable indicator of sample preservation (Ambrose 1990; Van Klinken 1999; Sealy et al. 2014). For bone collagen, the ideal range for $\% \mathrm{C}$ is c. $40-48 \%$, and for $\% \mathrm{~N}$ is approximately c. $12-17 \%-$ it should be noted these ranges are approximate, with individual studies (e.g. Ambrose 1990; Van Klinken 1999; Sealy et al. 2014) producing slightly different ranges. The purpose of these parameters is to ensure that sufficient organic material (e.g. mainly collagenous protein) was preserved, and that this material retains an acceptable in vivo signal (as assessed by the $C: N$ and collagen yield). Statistical analyses were performed in the open source statistics package R (http://www.r-project.org/).

\section{Stable isotope results}

The $\delta^{13} \mathrm{C}$ and $\delta^{15} \mathrm{~N}$ values are presented in Table 2. Of the 50 samples processed, 21 failed the quality control parameters, with 14 failing due to low or no collagen yield, and 7 failing due to $\mathrm{C}: \mathrm{N}$ ratios outside of the boundary 2:9-3:6 (DeNiro and Epstein 1978; Brock et al. 2010). These failed samples are listed below, but not included in statistical testing or interpretation. Table 2 also details human $\delta^{13} \mathrm{C}$ and $\delta^{15} \mathrm{~N}$ values from previous dietary studies at Yasinovatka (Lillie and Richards 2000:966, Lillie et al. 2011:62). These isotope values are integrated into the analysis below.

The majority of the $\delta^{13} \mathrm{C}$ and $\delta^{15} \mathrm{~N}$ results, at $-22.9 \pm 0.9$ and $13.8 \pm 1.5 \%$, clearly demonstrate that the majority of the individuals at Yasinovatka were reliant on aquatic protein as the mainstay of their diet (Fig. 7).

Two notable exceptions occur, burial 45 who produced a $\delta^{13} \mathrm{C}$ value of $-23.6 \%$ and a $\delta^{15} \mathrm{~N}$ value of $11.4 \%$, and burial 
Table $2 \quad \delta^{13} \mathrm{C}$ and $\delta^{15} \mathrm{~N}$ values of human bone collagen samples at Yasinovatka, where '-'denotes that no collagen yield was achieved. Results in italics = C:N ratios outside of the 2.9-3.6 boundary

\begin{tabular}{|c|c|c|c|c|}
\hline Sample & $\delta^{13} \mathrm{C}$ & $\delta^{15} \mathrm{~N}$ & $\mathrm{C}: \mathrm{N}$ & Source \\
\hline 1 & -24.1 & 14.4 & $4: 7$ & This study \\
\hline 2 & -23.0 & 14.8 & $3: 3$ & This study \\
\hline 3 & -23.1 & 13.8 & $3: 5$ & This study \\
\hline 4 & -23.3 & 14.1 & $3: 3$ & This study \\
\hline 5 & -22.2 & 14.1 & $3: 5$ & This study \\
\hline 6 & -24.0 & 13.9 & $4: 3$ & This study \\
\hline 7 & -22.4 & 13.9 & $3: 3$ & This study \\
\hline 8 & -22.8 & 14.2 & $3: 3$ & This study \\
\hline 9 & -23.4 & 13.9 & $3: 3$ & This study \\
\hline 10 & -23.0 & 14.6 & $3: 3$ & This study \\
\hline 11 & -24.0 & 14.7 & $4: 4$ & This study \\
\hline 12 & - & - & - & This study \\
\hline 14 & - & - & - & This study \\
\hline 15 & -23.5 & 12.8 & $3: 5$ & This study \\
\hline 17 & -23.1 & 14.1 & $3: 4$ & This study \\
\hline 18 & -22.6 & 12.5 & $3: 4$ & Lillie and Richards 2000 \\
\hline 19 & -22.4 & 7.4 & $3: 4$ & Lillie and Richards 2000 \\
\hline 20 & -21.6 & 13.3 & $3: 2$ & This study \\
\hline $20 a$ & -24.3 & 13.9 & $4: 7$ & This study \\
\hline 21 & -22.2 & 14.1 & $3: 1$ & This study \\
\hline $23 \mathrm{a}$ & -23.6 & 15.1 & $3: 5$ & This study \\
\hline $23 b$ & - & - & - & This study \\
\hline 24 & -24.1 & 13.6 & $4: 5$ & This study \\
\hline 25 & -23.2 & 14.2 & $3: 2$ & This study \\
\hline 26 & -24.2 & 7.6 & $4: 6$ & This study \\
\hline 27 & -25.6 & 14.6 & $3: 6$ & This study \\
\hline 28 & -22.3 & 12.7 & $3: 3$ & This study \\
\hline 30 & - & - & - & This study \\
\hline 31 & -22.5 & 12.4 & $2: 9$ & This study \\
\hline 32 & -23.5 & 13.7 & $3: 1$ & This study \\
\hline 34 & -23.8 & 14.8 & $3: 1$ & This study \\
\hline 35 & -23.7 & 15.0 & $3: 2$ & This study \\
\hline 36 & -22.5 & 13.9 & $3: 3$ & Lillie et al. 2011 \\
\hline 37 & -23.7 & 14.0 & $3: 1$ & This study \\
\hline 38 & -23.0 & 15.4 & $3: 4$ & This study \\
\hline 39 & - & - & - & This study \\
\hline 40 & -23.2 & 15.1 & $3: 5$ & This study \\
\hline 41 & - & - & - & This study \\
\hline 42 & - & - & - & This study \\
\hline 43 & - & - & - & This study \\
\hline 45 & -23.6 & 11.4 & $3: 2$ & This study \\
\hline 47 & - & - & - & This study \\
\hline 49 & - & - & - & This study \\
\hline 50 & - & - & - & This study \\
\hline 51 & - & - & - & This study \\
\hline 54 & -22.6 & 14.1 & 3.3 & Lillie et al. 2011 \\
\hline 55 & -23.0 & 14.4 & $3: 5$ & Lillie et al. 2011 \\
\hline
\end{tabular}

Table 2 (continued)

\begin{tabular}{lllll}
\hline Sample & $\delta^{13} \mathrm{C}$ & $\delta^{15} \mathrm{~N}$ & $\mathrm{C}: \mathrm{N}$ & Source \\
\hline 57 & & & & Lillie et al. 2011 \\
58 & - & - & - & This study \\
59 & -25.3 & 14.5 & $4: 5$ & This study \\
60 & -22.7 & 14.4 & $3: 1$ & This study \\
61 & - & - & - & This study \\
62 & -22.2 & 15.2 & $3: 2$ & This study \\
63 & -22.4 & 14.6 & 3.3 & Lillie et al. 2011 \\
64 & -30.8 & 14.5 & $2: 6$ & This study \\
65 & -20.3 & 12.5 & $3: 2$ & This study \\
\hline
\end{tabular}

19 , who produced a $\delta^{13} \mathrm{C}$ value of $-22.4 \%$ and a $\delta^{15} \mathrm{~N}$ value of $7.4 \%$. The $\delta^{15} \mathrm{~N}$ values of these individuals strongly support the consumption of $\mathrm{C}_{3}$ terrestrial plants and animals, with burial 19 (female, aged 20-25) most likely consuming less animal protein than burial 45 (male, aged $18-25$ ), as evidenced by her lower $\delta^{15} \mathrm{~N}$ value. Interestingly, their $\delta^{13} \mathrm{C}$ values are noticeably depleted compared with the (admittedly limited) fauna samples analysed from this region. This lends support to the possibility that these individuals were not consuming terrestrial plants and animals from this study region.

\section{Statistical testing}

The existing published isotope data from Yasinovatka (Lillie and Richards 2000; Lillie et al. 2011; Webster 1996) is integrated into the new dataset for statistical testing. Mann Whitney U tests (at alpha $=0.05$ ) were undertaken to investigate possible differences in $\delta^{13} \mathrm{C}$ and $\delta^{15} \mathrm{~N}$ values between the A-type and 5-pit burials (Mann Whitney $U$ is used as the residuals of the data are non-normally distributed). The difference in $\delta^{13} \mathrm{C}$ values between the $\mathrm{A}$-type and $\mathrm{S}$ pit burials is not significant at $p=0.238$, neither is the difference in $\delta^{15} \mathrm{~N}$ values at $p=0.352$. Of the 38 individuals that produced reliable isotope data, only 16 are securely sexed, and of those only three are identified as female. As a result, it is not possible to investigate dietary isotope difference by sex.

Of the A-type Surskaja burials, only select individuals were interred with grave goods, which consisted mainly of deer tooth pendants and fish teeth (Table 1). The difference in $\delta^{13} \mathrm{C}$ values between A-type individuals with grave goods and A-type individuals without, is not significant at $p=$ 0.984 , neither is the difference in $\delta^{15} \mathrm{~N}$ values $p=0.103$. Finally, individuals with grave goods and those without were tested without reference to A-type or $\mathrm{5}$ pit burials, and no difference is evident (with $\delta^{13} \mathrm{C}$ at $p=0.787$, and $\delta^{15} \mathrm{~N}$ at $p=0.158$ ). Tukey's outlier method was applied to the $\delta^{13} \mathrm{C}$ and $\delta^{15} \mathrm{~N}$ dataset, and identified two individuals with divergent $\delta^{15} \mathrm{~N}$ values - burial 45 at $11.4 \%$ and burial 19 at $7.4 \%$. 
Fig. 7 Individual human, faunal, and fish $\delta^{13} \mathrm{C}$ and $\delta^{15} \mathrm{~N}$ ratios for Yasinovatka, alongside averaged human and fauna $\delta^{13} \mathrm{C}$ and $\delta^{15} \mathrm{~N}$ ratios from the nearby contemporary sites of Dereivka, Nikolskoye, Vasilyevka V, Vyasivok, and the Crimean site of Fat'ma Koba. Note: this graph includes human $\delta^{13} \mathrm{C}$ and $\delta^{15} \mathrm{~N}$ data from Yasinovatka from a previous study (Lillie and Richards 2000:966, 2011: 62)

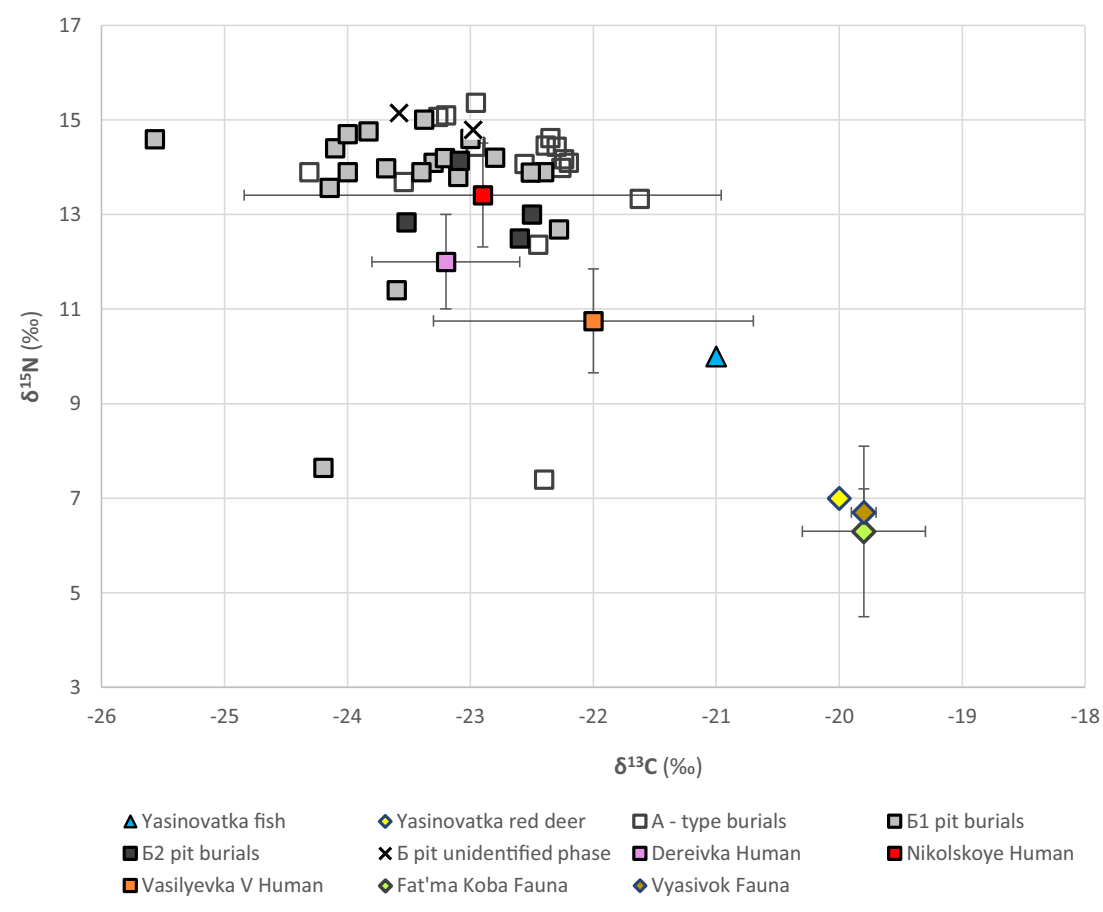

\section{Discussion}

Overall, the most striking conclusion evident from the human $\delta^{13} \mathrm{C}$ and $\delta^{15} \mathrm{~N}$ dataset is that it demonstrates a clear, continued, and heavy reliance on aquatic proteins into the Neolithic period, regardless of whether individuals show burial affinities with the Surskaja or Dnieper Donets cultural groups. Interestingly, two individuals stand out as being isotopically distinct in terms of their $\delta^{15} \mathrm{~N}$ values from the rest of the cemetery population, a young female found in close proximity to a deer tooth pendent (burial $19, \delta^{15} \mathrm{~N}=7.4 \%$ ), and the highly decorated young male with boar tusk plates sewn onto his clothing (burial $45, \delta^{15} \mathrm{~N}=11.4 \%$ ).

The isotope values for burial 19 could conceivably reflect the consumption of a plant dominated diet, as both her carbon and nitrogen isotopes mirror the fauna values measured at the Neolithic and Eneolithic phases at Molyukhov Bugor (Lillie et al. 2011). To date no other human sample in the study region has produced comparatively depleted $\delta^{15} \mathrm{~N}$ values (Lillie et al. 2011), although her value is in keeping with agragrian communities such as Trypillia (e.g. Lillie et al. 2017). Burial 19 has previously been analysed for dietary isotope analysis, and the original depleted $\delta^{15} \mathrm{~N}$ value led the authors to suggest the possibility of a misidentified faunal sample (Lillie et al. 2011; 64). For this study the bone sample was obtained directly from the individual's skull, and therefore the potential for misidentification is avoided.

The other outlier, burial 45 , is slightly more complex. His $\delta^{15} \mathrm{~N}$ value is easily in-keeping with a diet based on terrestrial animal protein with some contribution from terrestrial plants, but the $\delta^{13} \mathrm{C}$ value is distinctly depleted compared with the fauna analysed from the site. One possibility is that individual was consuming a combination of terrestrial fauna and selected aquatic remains from the region. The boar tusk plates that were sewn onto this individuals clothing may represent signifiers of his success as a hunter, and as such, provide an indication of at least one of the primary elements of his diet?

Support for the suggestion that aquatic resources may well have been important in the diet of individual 45 is found in the fish samples from the Neolithic sites of Dereivka $(n=1)$ and Vil'nyanka $(n=1)$, which have $\delta^{13} \mathrm{C}$ values of -25.5 and $26 \%$, and $\delta^{15} \mathrm{~N}$ values of 10.5 and $10 \%$ respectively, i.e. values that would be commensurate with a limited contribution of aquatic proteins for individual 45 . However, an alternative possibility is that the depleted $\delta^{13} \mathrm{C}$ values represent hunting and foraging of terrestrial species in woodland environments. For example, La Villette, Cuiry, Maizy, and Bercy are Neolithic sites located in close proximity to the River Seine within the Paris basin whose terrestrial wild and domesticate species have produced notably depleted $\delta^{13} \mathrm{C}$ values. Red and roe deer species have $\delta^{13} \mathrm{C}$ values of $c$. $-24.7 \%$, aurochs c. $-24 \%$, and Bos sp. of c. $-23.2 \%$ (see Goude and Fontugne 2016); demonstrating depleted terrestrial $\delta^{13} \mathrm{C}$ values are possible alongside freshwater/brackish river systems.

At the nearby Neolithic site of Dereivka (Fig. 1), two male individuals produced $\delta^{15} \mathrm{~N}$ values that were similarly divergent when compared with the majority of the cemetery population (with $\delta^{15} \mathrm{~N}$ values at $c .10 .5$ and $9.9 \%$ o, compared with a site average of $12 \pm 1 \%$, see Lillie et al. 2003, 2011). Burial 
49 , the individual with the lowest $\delta^{15} \mathrm{~N}$ value at $9.9 \%$, also represents the richest burial at Dereivka, and was interred with deer and fish tooth pendents, alongside a Mariupol plate that shows a distinct artefactual affinity with the 11 boar tusk ornaments associated with burial 45 at Yasinovatka.

As the majority of the adults analysed at Yasinovatka exhibit elevated $\delta^{15} \mathrm{~N}$ values, we can assess the presence of a reservoir effect given that earlier radiocarbon studies have shown the existence of an offset from one of the Yasinovatka burials (Lillie et al. 2009:261). For burial 54, with a $\delta^{15} \mathrm{~N}$ value of $14.1 \%$, we observe a chronological difference of $c .470$ years between the individual (human) and the deer tooth pendent that was dated. Several studies have investigated the relationship between dietary offsets and radiocarbon ages, variably applying regression and Bayesian modelling to calculate ${ }^{14} \mathrm{C}$ offsets using $\delta^{15} \mathrm{~N}$ values (Naito et al. 2010, Ramsey et al. 2014, Schulting et al. 2014, Sayle et al. 2016). At Yasinovatka, whilst investigations into the reservoir effect are currently limited to one burial, we can tentatively use the observed difference of $c .470$ years as a primary baseline for comparison. Assuming a very simple linear step-wise regression correction factor, we can use the $\delta^{15} \mathrm{~N}$ value of burial 54 (e.g. $14.1 \%$ ) as the upper end point for fish consumption, which has a corresponding ${ }^{14} \mathrm{C}$ offset of 470 years, and assume a $\delta^{15} \mathrm{~N}$ value of $10 \%$ o to reflect the consumption of $\mathrm{C}_{3}$ terrestrial proteins only (and therefore no reservoir offset). Using this basic approach, we can speculate ${ }^{14} \mathrm{C}$ offsets of between $c .240-470$ years for individuals with $\delta^{15} \mathrm{~N}$ values of 12 to $14 \%$. Interestingly, if we apply this ${ }^{14} \mathrm{C}$ correction factor to the dated individuals that have elevated $\delta^{15} \mathrm{~N}$ values, the oldest burials at the site are individual 45 (boar tusk plate burial) and individual 19. Both of these individuals exhibit $\delta^{13} \mathrm{C}$ and $\delta^{15} \mathrm{~N}$ values that are in-keeping with a $\mathrm{C}_{3}$ terrestrial diet.

It is, of course, difficult to accurately evaluate whether these individuals do in fact represent the oldest burials at the site, as research into the ${ }^{14} \mathrm{C}$ reservoir offset at Yasinovatka is limited, and the ${ }^{14} \mathrm{C}$ offset as applied here is a basic linear model. Obviously, the data indicates that an extended research program is necessary if we are to further disentangle the freshwater radiocarbon reservoir effect at Yasinovatka in more detail and with greater accuracy.

Overall, the combined research to date strongly supports the presence of fishing, hunting, and foraging/gathering activities in the Dnieper Rapids region from the Epipalaeolithic sites well into the Neolithic period. The degree to which these resources were exploited was probably dependant on a number of factors, including individual dietary preference, but also socio-economic factors, and potentially, political factors e.g. Rouja (1998). Ancient DNA analysis and craniometrics from individuals in the region support the possibility that human populations occupying the Dnieper Rapids were not necessarily indigenous to the region, with the presence of non-locals present from the Mesolithic period onwards (Lillie and Budd 2011, Lillie et al. 2012, Mathieson et al. 2018).

A preliminary, and indeed tentative suggestion, is that the individuals with comparatively depleted $\delta^{15} \mathrm{~N}$ values and associated decorative Mariupol-type boar tusk plates, perhaps represent the presence of non-local human groups either imposing themselves on the indigenous communities of the Dnieper Rapids region, or incomers to the region who represent marriage partners from other groups who would have cemented ties and rights of access to the rich resource base of the Dnieper Rapids region. Given the lack of evidence for inter-personal violence and the nature of the burials afforded to these individuals the latter scenario may well be the more realistic proposition at this stage. The re-use of the cemetery site at Yasinovatka, potentially with burial phases from at least two distinct cultural groups, supports the idea that access to the resources in this region was considered important across the Mesolithic and Neolithic periods, with the superimposition of the later cultures burials asserting ancestral legitimisation and also mirroring similar activities throughout prehistoric Europe (e.g. Zvelebil 1993; Lynch 2000).

\section{Conclusion}

At Yasinovatka the dietary isotope studies demonstrate that the majority of the population had a strong reliance on aquatic protein for the mainstay of their diet; thus highlighting the continued importance of fishing as a mainstay of subsistence strategies into the Neolithic period in the Dnieper Rapids region of Ukraine. The presence of two anomalous $\delta^{15} \mathrm{~N}$ values in the dataset is of interest, particularly as individual 45 shows close artefactual and isotopic affinities with similarly isotopically divergent individuals studied at the site of Dereivka. The lower $\delta^{15} \mathrm{~N}$ values for individual 19 at Yasinovatka could be indicating that some degree of population movement between the groups exploiting the region around the Dnieper is occurring across the Mesolithic to earlier Neolithic periods.

It is important to note that fishing was pivotal in terms of subsistence strategies from 10,200 calBC onwards in this region, and that despite assertions that climate influenced the timing and adoption of agriculture in Ukraine, regional variation and asynchronicity must be taken into account. In the Dnieper Region we see continuity in fisher-hunter-forager lifeways through to at least $c$. $3500 \mathrm{calBC}$, when areas of Ukraine to the west of the Dnieper have already developed some degree of pastoralism, with associated agricultural activity.

The fact that the major river valleys offered indigenous groups the opportunity to exploit a reliable suite of fish, animal and plant resources for in excess of 6500 years mirrors the exceptional situation occurring in the Baltic region, and provides an opportunity for long-term studies of food extraction societies at a time when farming is seen to be becoming the 
mainstay of subsistence in Neolithic Europe. The specific environmental context and significant areal extent of Ukraine in terms of its north-south and west-east climate, ecological and human activity zones offers a unique context for the study of prehistoric societies in the European mainland.

Funding Information Open access funding provided by Umeå University.

Open Access This article is licensed under a Creative Commons Attribution 4.0 International License, which permits use, sharing, adaptation, distribution and reproduction in any medium or format, as long as you give appropriate credit to the original author(s) and the source, provide a link to the Creative Commons licence, and indicate if changes were made. The images or other third party material in this article are included in the article's Creative Commons licence, unless indicated otherwise in a credit line to the material. If material is not included in the article's Creative Commons licence and your intended use is not permitted by statutory regulation or exceeds the permitted use, you will need to obtain permission directly from the copyright holder. To view a copy of this licence, visit http://creativecommons.org/licenses/by/4.0/.

\section{References}

Ambrose SH (1990) Preparation and characterization of bone and tooth collagen for isotopic analysis. J Archaeol Sci 17:431-451

Anthony, D.W., 2007. Pontic-Caspian Mesolithic and early Neolithic societies at the time of the Black Sea flood: a small audience and small effects. In The Black Sea flood question: changes in coastline, climate, and human settlement (pp. 345-370). Springer, Dordrecht

Ascough P, Cook G, Dugmore A (2005) Methodological approaches to determining the marine radiocarbon reservoir effect. Prog Phys Geogr 29(4):532-547

Barker G (2009) The agricultural revolution in prehistory: why did foragers become farmers?. Oxford University Press on Demand

Biagi P, Zaliznyak L, Kozłowski SK (2007) Old problems and new perspectives for the radiocarbon chronology of the Ukrainian Mesolithic. IGCP 521-481 Joint Meeting and Field Trip, Gelendzhik (Russia) - Kerch (Ukraine), September 8-17, 2007. pp. $27-30$

Bikoulis P (2015) Evaluating the impact of Black Sea flooding on the Neolithic of northern Turkey. World Archaeol 47(5):756-775

Bonsall C, Cook GT, Hedges RE, Higham TF, Pickard C, Radovanović I (2004) Radiocarbon and stable isotope evidence of dietary change from the Mesolithic to the Middle Ages in the Iron Gates: new results from Lepenski Vir. Radiocarbon 46(1):293-300

Brock F, Higham T, Ramsey CB (2010) Pre-screening techniques for identification of samples suitable for radiocarbon dating of poorly preserved bones. J Archaeol Sci 37:855-865

Cerling TE, Harris JM, MacFadden BJ, Leakey MG, Quade J, Eisenmann V, Ehleringer JR (1997) Global vegetation change through the Miocene/Pliocene boundary. Nature 389:153-158

Chambon P, Blin A, Bronk Ramsey C, Kromer B, Bayliss A, Beavan N, Healy F, Whittle A (2017) Collecting the dead: temporality and disposal in the Neolithic hypogée of les Mournouards II (Marne, France). Germania 95:93-143

DeNiro MJ (1985) Postmortem preservation and alteration of in vivo bone collagen isotope ratios in relation to palaeodietary reconstruction. Nature 317(6040):806

DeNiro MJ, Epstein S (1978) Influence of diet on the distribution of carbon isotopes in animals. Geochim Cosmochim Acta 42:495-506
Drucker DG, Valentin F, Thevenet C, Mordant D, Cottiaux R, Delsate D, Van Neer W (2018) Aquatic resources in human diet in the Late Mesolithic in Northern France and Luxembourg: insights from carbon, nitrogen and sulphur isotope ratios. Archaeol Anthropol Sci 10(2):351-368

Eriksson G (2006) Stable isotope analysis of human and faunal remains from Zvejnieki. In: Larsson L, Zagorska I (eds) Back to the origin: new research in the Mesolithic-Neolithic Zvejnieki cemetery and environment, northern Latvia. Sweden, Lund, pp 183-215

Eriksson G, Lõugas L, Zagorska I (2003) Stone age hunter-fishergatherers at Zvejnieki, northern Latvia: radiocarbon, stable isotope and archaeozoology data. Before farming 2003/1(2):1-26

Fernandes R, Millard AR, Brabec M, Nadeau MJ, Grootes P (2014) Food reconstruction using isotopic transferred signals (FRUITS): a Bayesian model for diet reconstruction. PLoS One 9(2):e87436

Fernández-Domínguez E, Reynolds L (2017) The Mesolithic-Neolithic transition in Europe: a perspective from ancient human DNA. In: García-Puchol O, Salazar-García DC (eds) Times of Neolithic transition along the Western Mediterranean. Springer, Switzerland, pp $311-338$

Gokhman II (1966) Naselenie Ukrainy v Epokhu Mezolita I Neolita: Anthropogicheskiy ocherk. (the population of Ukraine in the Mesolithic and Neolithic periods: an anthropological outline). Moscow: Nauka

Goldberg SL, Lau HC, Mitrovica JX, Latychev K (2016) The timing of the Black Sea flood event: insights from modeling of glacial isostatic adjustment. Earth Planet Sci Lett 452:178-184

Goude G, Fontugne M (2016) Carbon and nitrogen isotopic variability in bone collagen during the Neolithic period: influence of environmental factors and diet. J Archaeol Sci 70:117-131

Gronenborn D (2003) Migration, acculturation and culture change in western temperate Eurasia. Doc. Praehist. 30:79-91

Hedges REM, Reynard LM (2007) Nitrogen isotopes and the trophic level of humans in archaeology. J Archaeol Sci 34(8):1240-1251

Jacobs K (1993) Human postcranial variation in the Ukrainian Mesolithic-Neolithic. Curr Anthropol 34(3):311-324

Katzenberg MA, Weber A (1999) Stable isotope ecology and palaeodiet in the Lake Baikal region of Siberia. J Archaeol Sci 26:651-659

Kotova NS (2010) Chronology and periodization of the Surskaja Neolithic culture. Studia Archaeol. et Mediaeval. 11:67-90

Lee-Thorp J, Van der Merwe NJ (1987) Carbon isotope analysis of fossil bone apatite. S Afr J Sci 83:712-715

Lillie MC (1998) The Mesolithic-Neolithic transition in Ukraine: new radiocarbon determinations for the cemeteries of the Dnieper Rapids Region. Antiquity 72(275):184-188

Lillie M, Budd C (2011) The Mesolithic-Neolithic transition in Eastern Europe: integrating stable isotope studies of diet with palaeopathology to identify subsistence strategies and economy. Human Bioarchaeology of the Transition to Agriculture, pp43-62

Lillie M, Jacobs K (2006) Stable isotope analysis of 14 individuals from the Mesolithic cemetery of Vasilyevka II, Dnieper Rapids region, Ukraine. J Archaeol Sci 33(6):880-886

Lillie MC, Richards M (2000) Stable isotope analysis and dental evidence of diet at the Mesolithic-Neolithic transition in Ukraine. J Archaeol Sci 27(10):965-972

Lillie M, Richards MP, Jacobs K (2003) Stable isotope analysis of 21 individuals from the Epipalaeolithic cemetery of Vasilyevka III, Dnieper Rapids region, Ukraine. J Archaeol Sci 30(6):743-752

Lillie MC, Budd CE, Potekhina I, Hedges REM (2009) The radiocarbon reservoir effect: new evidence from the cemeteries of the middle and lower Dnieper basin, Ukraine. J Archaeol Sci 36:256-264

Lillie M, Budd C, Potekhina I (2011) Stable isotope analysis of prehistoric populations from the cemeteries of the middle and lower Dnieper Basin, Ukraine. J Archaeol Sci 38(1):57-68

Lillie MC, Potekhina ID, Budd CE, Nikitin A (2012) Prehistoric populations of Ukraine: migration at the later Mesolithic to Neolithic 
transition, in Kaiser, E., Burger, J. and W. Schier (eds.) Population dynamics in prehistory and early history. New approaches using stable isotopes and genetics. Berlin: de Gruyter. pp. 77-92

Lillie MC, Budd CE, Potekhina I, Price TD, Sokhatsky MP and Nikitin AG (2017) First isotope analysis and new radiocarbon dating of Trypillia (Tripolye) farmers from Verteba Cave, Bilche Zolote, Ukraine Documenta Praehistorica XLIV:306-24. DOI: https://doi. org/10.4312/dp.44.18

Longin R (1971) New method of collagen extraction for radiocarbon dating. Nature 230(5291):241

Lynch F (2000) The Later Neolithic and Earlier Bronze Age, In: Lynch, F., Aldhouse-Green, S. and J.L. Davies (eds.) Prehistoric Wales. Gloucestershire: Sutton Publishing Ltd. pp. 79-138

Makarewicz CA, Sealy J (2015) Dietary reconstruction, mobility, and the analysis of ancient skeletal tissues: expanding the prospects of stable isotope research in archaeology. J Archaeol Sci 56:146-158

Mathieson I, Alpaslan-Roodenberg S, Posth C, Szécsényi-Nagy A, Rohland N, Mallick S, Olalde I, Broomandkhoshbacht N, Candilio F, Cheronet O, Fernandes D (2018 Mar) The genomic history of southeastern Europe. Nature. 555(7695):197

Meyer C, Ganslmeier R, Dresely V, Alt KW (2012) New approaches to the reconstruction of kinship and social structure based on bioarchaeological analysis of Neolithic multiple and collective graves. Theoretical and methodological considerations in central European Neolithic archaeology, Oxford (BAR international series 2325), pp.11-23

Milner N, Craig OE, Bailey GN, Pedersen K, Andersen SH (2004) Something fishy in the Neolithic? A re-evaluation of stable isotope analysis of Mesolithic and Neolithic coastal populations. Antiquity 78(299):9-22

Minagawa M, Wada E (1984) Stepwise enrichment of ${ }^{15} \mathrm{~N}$ along food chains: further evidence and the relation between $\delta^{15} \mathrm{~N}$ and animal age. Geochim Cosmochim Acta 48:1135-1140

Motuzaite Matuzeviciute G (2014) Neolithic of Ukraine: a review of theoretical and chronological interpretations. Archaeologia Baltica 20:136-149

Naito YI, Chikaraishi Y, Ohkouchi N, Mukai H, Shibata Y, Honch NV, Dodo Y, Ishida H, Amano T, Ono H, Yoneda M (2010) Dietary reconstruction of the Okhotsk culture of Hokkaido, Japan, based on nitrogen composition of amino acids: implications for correction of $14 \mathrm{C}$ marine reservoir effects on human bones. Radiocarbon 52(2):671-681

Naito YI, Chikaraishi Y, Ohkouchi N, Yoneda M (2013) Evaluation of carnivory in inland Jomon hunter-gatherers based on nitrogen isotopic compositions of individual amino acids in bone collagen. $\mathrm{J}$ Archaeol Sci 40:2913-2923

Nikitin AG, Sokhatsky MP, Kovaliukh MM, Videiko MY (2010) Comprehensive site chronology and ancient mitochondrail DNA analysis from Verteba cave - a Trypillian culture site of Eneolithic Ukraine. Interdiscip. Archaeol. 1(1-2):9-18

Nikitin AG, Potekhina ID, Rohland N, Mallick S, Reich D, Lillie M (2017) Mitochondrial DNA analysis of Eneolithic Trypillians from Ukraine reveals Neolithic farming genetic roots. PLoS One 12(2): e0172952

O'Connell TC, Kneale CJ, Tasevska N, Kuhnle GG (2012) The diet-body offset in human nitrogen isotopic values: a controlled dietary study. Am J Phys Anthropol 149(3):426-434

Paula J Reimer, Edouard Bard, Alex Bayliss, J Warren Beck, Paul G Blackwell, Christopher Bronk Ramsey, Caitlin E Buck, Hai Cheng, R Lawrence Edwards, Michael Friedrich, Pieter M Grootes, Thomas P Guilderson, Haflidi Haflidason, Irka Hajdas, Christine Hatté, Timothy J Heaton, Dirk L Hoffmann, Alan G Hogg, Konrad A Hughen, K Felix Kaiser, Bernd Kromer, Sturt W Manning, Mu Niu, Ron W Reimer, David A Richards, E Marian Scott, John R Southon, Richard A Staff, Christian S M Turney, Johannes van der Plicht, (2013) IntCal13 and Marine13
Radiocarbon Age Calibration Curves 0-50,000 Years cal BP. Radiocarbon 55(4):1869-1887

Pearson MP (1999) The archaeology of death and burial (p. 44). Phoenix Mill, Sutton: Sutton

Philippsen B (2013) The freshwater reservoir effect in radiocarbon dating. Herit. Sci. 1(1):24

Pluciennik M (1998) Deconstructing 'the Neolithic' in the MesolithicNeolithic transition. In: Edmonds M, Richards C (eds) Understanding the Neolithic of North-Western Europe. Cruithne Press, Glasgow, pp 61-83

Price TD (2000) Europe's first farmers. Cambridge University Press

Ramsey CB, Schulting R, Goriunova OI, Bazaliiskii VI, Weber AW (2014) Analyzing radiocarbon reservoir offsets through stable nitrogen isotopes and Bayesian modeling: a case study using paired human and faunal remains from the Cis-Baikal region, Siberia. Radiocarbon 56(2):789-799

Richards MP (2002) A brief review of the archaeological evidence for Palaeolithic and Neolithic subsistence. Eur J Clin Nutr 56:12

Richards MP, Schulting RJ, Hedges REM (2003) Sharp shift in diet at the onset of the Neolithic. Nature 425:366

Robson HK, Andersen SH, Clarke L, Craig OE, Gron KJ, Jones AKG, Karston P, Milner N, Douglas Price T, Ritchie K, Zabilska-Kunek M, Heron C (2016) Carbon and nitrogen stable isotope values in freshwater, brackish and marine fish bone collagen from Mesolithic and Neolithic sites in central and northern Europe. Environ Archaeol 21:105-118

Rouja PM (1998) Fishing for culture: towards an aboriginal theory of marine resource use among the Bardi aborigines of One Arm Point, Western Australia. Durham University: Unpublished PhD Thesis (Department of Anthropology)

Ryan WB, Major CO, Lericolais G, Goldstein SL (2003) Catastrophic flooding of the Black Sea. Annu Rev Earth Planet Sci 31(1):525554

Salanova L, Chambon P, Bayliss A, Healy F, Whittle A (2018) Violent deaths in the development of the farming economy: the case of Bury. Jour. Neolit. Archaeol. 20:1-11

Sayle KL, Hamilton WD, Gestsdóttir H, Cook GT (2016) Modelling Lake Mývatn's freshwater reservoir effect: utilisation of the statistical program FRUITS to assist in the re-interpretation of radiocarbon dates from a cemetery at Hofstaðir, north-east Iceland. Quat Geochronol 36:1-11

Schmölcke U, Meadows J, Ritchie K and Bērziņš V, Lübke H, Zagorska I (2015) Neolithic fish remains from the freshwater shell midden Rinnukalns in northern Latvia. Environ. Archaeol: 1-14

Schoeninger MJ, DeNiro MJ (1984) Nitrogen and carbon isotopic composition of bone collagen from marine and terrestrial animals. Geochim Cosmochim Acta 48:625-639

Schulting RJ, Ramsey CB, Bazaliiskii VI, Goriunova OI, Weber A (2014) Freshwater reservoir offsets investigated through paired humanfaunal $14 \mathrm{C}$ dating and stable carbon and nitrogen isotope analysis at Lake Baikal, Siberia. Radiocarbon 56(3):991-1008

Schwarcz HP, Schoeninger MJ (1991) Stable isotope analyses in human nutritional ecology. Am J Phys Anthropol 34:283-321

Sealy JC, Johnson M, Richards M, Nehlich O (2014) Comparison of two methods of extracting bone collagen for stable carbon and nitrogen isotope analysis: comparing whole bone demineralization with gelatinization and ultrafiltration. J Archaeol Sci 47:64-69

Sherratt A (2016) Diverse origins: regional contributions to the genesis of farming. In The origins and spread of domestic plants in southwest Asia and Europe (pp. 17-36). Routledge

Styring AK, Fraser RA, Arbogast RM, Halstead P, Isaakidou V, Pearson JA, Schäfer M, Triantaphyllou S, Valamoti SM, Wallace M, Bogaard A (2015) Refining human palaeodietary reconstruction using amino acid $\delta^{15} \mathrm{~N}$ values of plants, animals and humans. J Archaeol Sci 53:504-515 
Svyatko SV, Mertz IV, Reimer PJ (2015) Freshwater reservoir effect on redating of Eurasian steppe cultures: first results for Eneolithic and early bronze age Northeast Kazakhstan. Radiocarbon 57(4):625644. https://doi.org/10.2458/azu_rc.57.18431

Svyatko S, Schulting R, Poliakov A, Ogle N, Reimer PJ (2016) A lack of freshwater reservoir effects in human radiocarbon dates in the Eneolithic to Iron age in the Minusinsk Basin. Archaeol Anthropol Sci 9:1379-1388. https://doi.org/10.1007/s12520-016-0383-3

Telegin DY (1968) Dnipro-donetska kultura. (the Dnieper-donets culture). Naukova Dumka, Kiev

Telegin DY (1973) Seredno-stogivska Kultura Epoki Midi. (The SredniStog Culure Middle Period). Naukova Dumka, Kiev

Telegin DY, Potekhina ID (1987) Neolithic cemeteries and populations in the Dnieper Basin (BAR international series 383)

Telegin D, Titova EN (1993) Settlements of Neolithic stage DniproDonetz etnocultural community

Telegin DY, Potekhina ID, Lillie M, Kovaliukh MM (2002) The chronology of the Mariupol-type cemeteries of Ukraine re-visited. Antiquity 76(292):356-363

Telegin DY, Lillie M, Potekhina ID, Kovaliukh MM (2003) Settlement and economy in Neolithic Ukraine: a new chronology. Antiquity 77(297):456-470

Thomas J (2002) Understanding the neolithic. Routledge

Turney CS, Brown H (2007) Catastrophic early Holocene Sea level rise, human migration and the Neolithic transition in Europe. Quat Sci Rev 26(17-18):2036-2041
Van Klinken GJ (1999) Bone collagen quality indicators for palaeodietary and radiocarbon measurements. J Archaeol Sci 26(6):687-695

Webster CL (1996) Dietary reconstruction of 8 Ukrainian cultures using $\delta^{13} \mathrm{C}$ and $\delta^{15} \mathrm{~N}$ analysis. Queens University Belfast: Unpublished MA Thesis

Whittle AWR, Healy FMA, Bayliss A (2011) Gathering time: dating the early Neolithic enclosures of southern Britain and Ireland. Oxbow Books

Yanchilina AG, Ryan WB, McManus JF, Dimitrov P, Dimitrov D, Slavova K, Filipova-Marinova M (2017) Compilation of geophysical, geochronological, and geochemical evidence indicates a rapid Mediterranean-derived submergence of the Black Sea's shelf and subsequent substantial salinification in the early Holocene. Mar Geol 383:14-34

Zvelebil M (1993) Hunters or farmers? The Neolithic and bronze age societies of north-East Europe, In: Chapman, J. and P. Dolukhanov (eds.) Cultural Transformations and Interactions in Eastern Europe. Aldershot: Ashgate Publising (World Archaeology Series. pp. 14662

Zvelebil M (1998) What's in a name: the Mesolithic, the Neolithic and social change at the Mesolithic-Neolithic transition. In: Edmonds M, Richards C (eds) Social life and social change: the Neolithic of North Western Europe. Routledge, London, pp 1-36

Publisher's note Springer Nature remains neutral with regard to jurisdictional claims in published maps and institutional affiliations. 